\title{
The Improvement of Teacher's Ability in Creating Innovative Lesson Plan through Discussion with Practice
}

\author{
Sudibyo* \\ Dinas Pendidikan Kabupaten Situbondo
}

*Coressponding author Sudibyo

\sudibyo04@yahoo.com

\begin{abstract}
This study aims to describe the improving commitment and teacher's ability in creating an innovative lesson plan through practice work with feedback. The method use classroom action research in two cycles. The results are: (1) improvement of teacher's commitment in designing innovative lesson plan, with $92 \%$ of teachers can reach minimum score of 4,00-5,00 in widescale 1-5; and (2) improvement of teachers' ability to designing innovative lesson plan, with $92 \%$ of teachers are able to reach minimum score of 4,00-5,00. The strategy of practice work with feedback proves to increase the teachers' work in designing an innovative lesson plan.
\end{abstract}

Keywords

teacher's ability; innovative; lesson plan; discussion

\section{INTRODUCTION}

The steps of learning described in teachers' lesson plan show that learning and teaching used is being dominated by teacher center oriented, using behavioristic learning strategy dominated by speech, discussion, and questionnaire. Almost there is no lesson using student center oriented with the discovery inquiry approach so that there is no appearing exploration, elaboration, and confirmation from students. The design must be organized because lesson plan is used as the reference and teachers' guidelines. Quality improvement must be started by the repairing of teaching and learning design. Yet, it is the effort to the better quality of education.

There are several causes of problems in the preparation of Lesson Plan scenarios, namely: (1) lack of supervisor demands (Principal and School Supervisor), because it still allows the use of Lesson Plan made by Teachers Working Group (TWG), with the assumption that working together and in a higher level is better. Although it is not always in accordance with the conditions of each school; (2) during this Lesson Plan is not used as a guide in implementing the learning process but only shown to the supervisor as physical evidence only; so that the implementation in front of the class is different from the scenario written in the Lesson Plan.

Two factors that need attention are: (1) Commitment of teachers. Most teachers are complacent, using only TWG-made Lesson Plans with the assumption that joint work at a higher level is better. The Lesson Plan is only as physical evidence when doing supervision; (2) The ability of teachers. As a result, most teachers lack the ability to develop a Lesson Plan. The absence of learning experience, causing teachers not to have the skills to prepare a Lesson Plan.

Improving the skills of teachers in preparing the lesson plan, the most appropriate method in this study is practical work because it can create a learning experience for teachers. Practical work is a strategic choice that is expected to solve the problem of low commitment and ability of teachers to prepare Lesson Plan. Techniques of feedback on the work of teachers are expected to provide support and direction to make improvements to the Lesson Plan. Departing from that foundation, this study was conducted with the aim of: (1) Increasing the commitment of teachers SDN 3 Wringin Anom compiled the innovative Lesson Plan in the activities of Work Practices with feedback techniques; (2) Improvement of SDN 3 Wringin Anom teacher's ability to compose Innovative Lesson Plan in Practice Work activities with Feedback techniques. 


\section{METHODS}

The stages of this research are the school action research design. The research process is done through a cycle from planning, action implementation, observation and reflection. Research cycle is done twice to get good action result. This research was conducted at SDN 3 Wringin Anom.

The first step is planning with the principal and the teaching team to determine the steps that need to be done in the research process, whose goal is "Improving the Ability of the Teacher to Prepare Innovative Learning Plan through Discussion with Work Practice". The second step is the commitment and the ability of teachers to make innovative Lesson Plan. As the independent variable is the "Practice Work strategy with feedback technique", and the dependent variable is the teacher's "commitment" and "ability" to draw up the Innovative Lesson Plan. The third step is to carry out observations or observations on the implementation of the action by using the observation sheet that has been set. The fourth step is to hold a reflection based on the data obtained from the collected and analyzed observations intended to know the teacher's initial skill in preparing the lesson plan prior to the action.

Supervisor collects each Lesson Plan. Then assessing, giving feedback based on 8 (eight) components in accordance with the format of the assessment of the Lesson Plan in the Guidance of Master Certification of Portfolio Tool in Position, Direktorat Jenderal Pendidikan Tinggi (2007), namely: (a) Clarity of learning objectives formulation; (b) Selection of teaching materials; (c) Organizing teaching materials; (d) Selection of learning resources / media.

The main data sources examined are all classroom teachers and subject teachers in SDN 3 Wringin Anom including the principal because the principal is a teacher who gets extra duty, according to the rule of the principal still has the duty to teach as many as 6 (six) hour/week. Research subjects were 12 people consisting of 6 class teachers, 1 sports teacher, 2 Madurese language teachers, 1 English teacher and 2 teachers of Arts.

\section{RESULTS}

This school action research is conducted in two rounds, to improve teachers' skills in preparing Lesson Plan, the method used is practical work to create a learning experience for teachers in overcoming the low commitment and ability of teachers to develop Lesson Plan.

\section{Cycle I}

Steps of activities in the preparation of innovative Lesson Plan, first: Group formation: Subject Group (Bahasa, MIPA, IPS and others) and meeting schedule, which includes Class IV teacher group, class V teacher group and class VI teacher group by linking technique of formulation of learning steps of Innovative LESSON PLAN with conventional pattern. The second step is assigning the tasks to the teacher according to the class group. The third step is monitored duty practice (time limits) to revise the compiled Lesson Plan. The fourth step is to collect data on teacher commitment in conducting activities, to assess teacher's ability to revise Lesson Plan, and to examine the results achieved during the implementation of the action, as well as its efforts and corrective plans.

The ability of teachers to prepare the lesson plan before action can be assessed from the initial LESSON PLAN that teachers gather, the average ability of all teachers of SDN 3 Wringin Anom (12 persons) is 1.25 on a scale of 1-5. Means that there is no teacher achieving a value of 4.00 to $5.00(0 \%)$. Factors are: (1) Teachers do not fully demonstrate the commitment of good value in cycle I as a component of time, i.e. joining every activity, attending/going home on time and completing the task on time with a value: average W1 5,00; W2 averages 4.25. Teachers with a commitment value of 4.00-5.00 reached 41.66\%; (2) three out of four senior teachers of SDN 3 Wringin Anom who followed the certification test do not prepare the Lesson Plan; (3) There are teachers (about 90\%) are incapable of preparing Lesson Plan.

In terms of individual/personal teachers, more Lesson Plan owned is the result of collective activities such as from the production of GFC Cluster. Departing from these two weaknesses, it is necessary to make improvements for the implementation of the next cycle.

\section{Cycle II}

The step in cycle II achieving teacher performance indicators, with the form of activities: (1) Giving the task with the target (determined amount) Lesson Plan to be completed. Teachers independently in groups carrying out unfounded discussions. It is expected that each teacher will produce 1 (one) Innovative Lesson Plan; (2) Observe the following: (a) Assessment of teachers' commitment to carry out activities, the observer 
is conducted by 2 persons (1 supervisor, 1 principal); (b) Assessment of teachers' ability in preparing innovative LESSON PLAN through document collection, also performed by 1 supervisor and 1 school principal.

Assessing the results of data obtained for teacher commitment to formulate innovative LESSON PLAN both regarding teacher activity in formal meetings or homework activities and after presented innovative learning models (cooperative learning, contextual teaching and learning, etc.), teacher commitment to the components of encouragement and effort showed a fairly high increase, reaching an average value of over 4.17. Teachers who scored from 4.00 to 5.00 achieved $92 \%$. From the interviews, the new teachers know that so many learning models must be understood to change to the discovery inquiry approach.

According to teachers, there is an increase in curiosity that encourages them to continue learning. The reason is that applying pursing models makes it easier for teachers to make innovative LESSON PLANs because the syntax of each learning model is very clear. Teachers are very helpful in making studentcentered learning strategies with discovery inquiry approach. The motivation of teachers began to grow, because the models of practical work forms are highly favored by teachers. According to the teacher, it is much different from previous models that rely on forms of teacher center/lecture.

There is a considerable increase in the value of the ability (teacher) in the preparation of the Lesson Plan - Innovative from Cycle I to Cycle II. The average teacher's ability to increase to 4.18 and there is only 1 teacher whose value is less than 4.00. At the end of cycle II, teachers who scored from 4.00 to 5.00 increased by $92 \%$. This is supported by the results of interviews with teachers, that teachers find it very easy to develop innovative LESSON PLANs because they understand the learning models with their syntaxes. The key to success in cycle II is the use of Innovative Patterns: Strategy or Retrieval Model, to support discovery inquiry strategy.

\section{DISCUSSIONS}

Based on the results of the school action research conducted two rounds, that through practical work and feedback can increase / activeness of commitment and the ability of teachers in the preparation of Innovative Lesson Plan. Innovative Lesson Plan derived from innovation means renewal or word changes (in) new. The innovative LESSON PLAN is the renewal which refers to the National Education Ministerial Elucidation No. 41 of 2007 on Standard Process of Primary and Secondary Education. "The Lesson Plan (LESSON PLAN) is a plan that describes the procedure and organizing the learning to achieve a basic competency defined in the content standard and has been described in the syllabus." The LESSON PLAN component consists of (a) the subject identity, (b) the competency standard, c) basic competence, (d) competency achievement indicators, (e) learning objectives, (f) teaching materials, (g) time allocation, (h) learning methods, (i) learning activities include: introduction, core, $\mathrm{j}$ ) learning resources, and (k) assessment of learning outcomes include: questions, scores and key answers (Departemen Pendidikan Nasional, 2007b). Increased Commitment to teachers during the implementation of the action. The following table 1 shows the tendency of increasing the commitment value of teachers to develop innovative LESSON PLAN.

Interpretation: (1) Increasing the commitment value of teachers makes the innovative LESSON PLAN from cycle I to cycle II of 0.40 (on a scale of $1-5$ ) ie from 3.77 to 4.17 ; (2) The number of teachers who reached the value of more than 4.00 as many as 11 persons (92\%). The percentage increase is $50 \%$ ie from $42 \%$ to $92 \%$; (3) so the performance indicator for teacher commitment increase of $85 \%$ from the number of teachers has been achieved in cycle II with the achievement of $92 \%$.

Based on the bar chart seen that: (1) Graphic 1: increase the commitment value of teachers parabolic shaped. That means a sharper increase is in the early cycle (end of cycle I to end of cycle II) from 3.77 to 4.17; (2) Graphic 2: The percentage increment from 4.00 to 5.00 is quite sharp in cycle II (end of cycle I to end of cycle II) from $42 \%$ to $92 \%$.

Tabel 1. The Improvement of Commitment Teachers

\begin{tabular}{clccc}
\hline No & \multicolumn{1}{c}{ Description } & Cycle I & Cycle II & Total Increase \\
\hline 1 & $\begin{array}{l}\text { Average commitment } \\
\text { Number of teachers by the score of } \\
2.00-5.00\end{array}$ & 3.77 & 4.17 & 0.40 \\
3 & \begin{tabular}{l} 
Teachers' percentage of $4.00-5.00$ \\
\hline
\end{tabular} & $42 \%$ & $92 \%$ & 6 persons \\
\hline
\end{tabular}


Tabel 2. The Improvement of Teachers' Ability

\begin{tabular}{|c|c|c|c|c|c|}
\hline No & Description & Early & Cycle I & Cycle II & Total Increase \\
\hline 1 & Average ability & 1.52 & 3,72 & 4,18 & 2.66 \\
\hline 2 & $\begin{array}{l}\text { Number of teachers by the } \\
\text { score of } 4.00-5.00\end{array}$ & 0 & 4 & 11 & 11 persons \\
\hline 3 & $\begin{array}{l}\text { Teachers' percentage of } 4.00 \\
-5.00\end{array}$ & $0 \%$ & $33.3 \%$ & $92 \%$ & $92 \%$ \\
\hline
\end{tabular}

Interpretation: (1) There is an increase in the ability of teachers to make innovative Lesson Plan from cycle II to 2.66 (scale 1-5) from 1.52 to 4.18 . (1) The number of teachers who reached a score of 4.00 to 5.00 increased by 11 persons from 12 persons. Percentage of teachers who achieved grades from 4.00 to 5.09 was $92 \%$ of 16 teachers, and (2) So, performance indicators were achieved in cycle III, with $88 \%$ achievement. Each teacher is required to have four competencies, as regulated in the Regulation of Peraturan Menteri Pendidikan Nasional Nomor 16 Tahun 2007 covering: (a) Pedagogic competence; (b) Personality competence; (c) Professional competence; and (d) Social Competence. Pedagogic competence is related to teacher's ability and commitment in designing learning, conducting learning, evaluating, conducting an analysis of evaluation result and implementing remedial and enrichment program (Departemen Pendidikan Nasional, 2007a). Competence includes the cognitive, psychomotor and affective domains. In the case of Lesson Plan preparation, the cognitive is the knowledge of LESSON PLAN preparation procedures, the psychomotor is the skill of preparing the lesson plan, and the affective is the commitment in preparing the LESSON PLAN.

The Government has formulated four types of teacher competence as stated in the explanation of Peraturan Pemerintah Nomor 19 Tahun 2005 about the National Education Standards. One of the competencies that need to be possessed is Pedagogic Competence, that is the ability in the management of learners which include: (a) understanding of knowledge or educational background; (b) understanding of learners; (c) curriculum / syllabus development; (d) learning design; (e) the implementation of educational and dialogical learning; (f) evaluation of learning outcomes; ( $g$ ) the development of learners to actualize their potentials (Departemen Pendidikan Nasional, 2005). From the bar chart seen: Diagram 3, the value of the ability of teachers to rise stagnant (increasing) parabolic. This means that a sharp increase occurs in cycle I (from the initial condition to the end of the cycle I) from 1.52 to 3.72. Furthermore, the increase slightly sloping from 3.72 to 4.18 in cycle II. Grapic 4: the percentage of teachers who achieved a score of 4.00 5.00 from cycle I to cycle II rose monotonically with an increase of $58.7 \%$. The increase from an initial condition to cycle I is still sloping (from $0 \%$ to $33.3 \%$ ), but in cycle II (end of cycles I to end of cycle II) there is a very sharp increase $(33.3 \%$ to $92 \%)$.

Pedagogic competence is related to a teacher's ability and commitment in designing learning, conducting learning, evaluating, conducting an analysis of evaluation result and executing remedial and enrichment program. Competence includes the cognitive, psychomotor and affective domains. In the case of Lesson Plan preparation, the cognitive is the knowledge of LESSON PLAN preparation procedures, the psychomotor is the skill of preparing the lesson plan, and the affective is the commitment in preparing the Lesson Plan. This activity is intended to determine the initial ability of teachers to arrange the lesson plan prior to the action. Gather each Lesson plan that has been created by the. Then reviewed and assessed, given feedback based on the 8 components in accordance with the format of assessment of the LESSON PLAN in the Guidance of In-Service Master Portfolio Compilation, Directorate General of Higher Education (2007: 36), namely: (a) Clarity of the formulation of learning objectives; (b) Selection of teaching materials; (c) Organizing teaching materials; and (d) Selection of learning resources / media.

Teachers' ability to teach is actually a reflection of mastery over their competence. A good teacher must master at least ten basic competencies, namely: (1) Mastering materials; (2) Mastering the educational foundation; (3) Develop teaching programs; (4) Implementing the teaching program; (5) Assessing the learning process and outcomes; (6) Conducting a counseling guidance program; (7) Organizing school administration; (8) Developing personality; (9) Interacting with peers and communities; and (10) Conducting simple research for teaching purposes (Imron, 1995). All competencies are then grouped into three basic competencies, namely ability: plan, implement, and evaluate teaching. The basic competence of teaching is done in learning through the development of an updated Lesson plan, an innovative Lesson plan that supports learning for better learning outcomes. Making Lesson plan is very urgent, according to Uno (2006) 
improving the quality of learning must begin with the improvement of instructional design. Learning Planning can be a starting point for improving the quality of learning.

\section{CONCLUSIONS}

Based on the results of research and assessment, it can be concluded that: Job Training activities with Feedback techniques prove to increase teacher commitment SDN 3 Wringin Anom in preparing Innovative Lesson Plan. Performance indicators: At least $85 \%$ of teachers demonstrate a good commitment in developing innovative Lesson Plan (average score 4.00-5.00) on a scale of 1-5, reached at the end of cycle II with the achievement of $92 \%$. Upon the results achieved in this study, the author recommends to the related parties to improve the quality of educators, namely: (1) The school Principal, to revise the ways of improving the quality of educators, from the exposure model facto into a form of real practice sustainably. Many previous facto exposure models proved incapable of empowering teachers; (2) Education Supervisors, in terms of improving the quality of educators is not a simple matter. It needs continuous efforts to carry out supervision, so that the pattern of learning does not come back to the conventional pattern, because the pattern is not matched again with the Peraturan Menteri Pendidikan Nasional Nomor 41 Tahun 2007.

\section{REFERENCES}

Departemen Pendidikan Nasional. (2005). Peraturan Pemerintah Nomor 19 Tahun 2005 tentang Standar Nasional Pendidikan. Jakarta: Depdiknas.

Departemen Pendidikan Nasional. (2007). Peraturan Menteri Pendidikan Nasional Nomor 16 Tahun 2007 tentang Kualifikasi Akademik dan Kompetensi Guru. Jakarta: Depdiknas.

Departemen Pendidikan Nasional. (2007). Peraturan Menteri Pendidikan Nasional Nomor 41 Tahun 2007 tentang Standar Proses Pendidikan Dasar dan Menengah. Jakarta: Depdiknas.

Direktorat Jenderal Pendidikan Tinggi. (2007). Panduan Penyusunan Perangkat Portofolio Sertifikasi Guru dalam Jabatan. Jakarta: Depdiknas.

Imron, A. (1995). Pembinaan Guru di Indonesia. Malang: Pustaka Jaya.

Uno, H. B. (2006). Perencanaan Pembelajaran. Jakarta: Bumi Aksara. 
20 International Research-Based Education Journal, Vol 2 No 12020

This page is intentionally left blank 